provision had been made for the appropriate behaviour along with the appropriate physical apparatus for nurturance.

Nicholson's treatment of differences in aggression is equally odd. Having quoted a mass of evidence that suggests that men are more aggressive than women, he writes "In the absence of evidence to the contrary, I suggest we assume that men are more aggressive than women". Elsewhere he tries to dispose of the argument that the greater tendency of males to be aggressive is - at least in part - caused by the presence of higher levels of testosterone. He cites the case of girls who were exposed as fetuses to exceptionally high levels of androgens and notes that their behaviour tends to be tomboyish, but he fails to draw the obvious conclusion.

Despite his bias against biological explanations, Nicholson writes clearly though without much wit or charisma. Some of the results he provides may titivate. Half of American fathers have never changed a nappy - not even a disposable one; the difference in the athletic records of men and women has been enormously reduced over the past 50 years (one hopes this has nothing to do with steroids); women's scores on examinations are not influenced by the point in the menstrual cycle at which they take them; men and women do not differ in selfesteem, ambition or ability, but men are the more confident sex.

Since Nicholson virtually rules out innate factors as responsible for the differences between men and women, he is not unnaturally puzzled that all known societies are patriarchal: men occupy the prestigious jobs, and in encounters between members of the opposite sex, both men and women almost invariably feel that the man is dominant. One of his proposed solutions is that men's aggression and desire to dominate stems from their shame that they cannot have babies, a proposal that could surely be disposed of fairly quickly by a social survey - unless of course the hurt goes so deep that men are ashamed to admit it. There is another possibility that he does not consider. Perhaps men and women are innately disposed to act in different ways to members of the opposite sex. This would account for much of the evidence he quotes, for example, the fact that both men and women treat boy and girl babies differently even when the have been misled about the sex of the baby. The initial bias would determine the process of socialization, which would in turn increase the bias. The explanation would also account for one of Nicholson's recurrent themes: despite the feminist movement, it is hard to demonstrate any significant changes over the past 20 years in attitudes or practices relating to the interaction of the sexes.

Stuart Sutherland is Director of the Centre for Research on Perception and Cognition, University of Sussex.

\section{Histochemistry and cytology}

\section{Robert Olby}

History of Staining, 3rd Edn.

By George Clark and Frederick $\mathrm{H}$. Kasten.

Williams \& Wilkins: 1983. Pp.304. $\$ 29.95, £ 22.25$.

A SERIES of articles published in the journal Stain Technology between 1928 and 1933 formed the text of the first edition of this book, which was compiled by H. J. Conn and appeared in 1933. With the additions to the second (1948) and present (third) editions, the book is now virtually twice its original size. Successive editions have followed Conn's intention, which was to cover the field broadly rather than going deeply into specialized topics. As is typical of collections of reprinted papers, there was in the original book a lack of any overall thesis which might have acted as an organizing principle; unhappily, this feature has been perpetuated rather than overcome in the later editions.

The subject matter in this new edition has been organized in terms of, first, the different sorts of dyes, second, the several kinds of biological materials - bacteria, blood, connective tissue, nerve tissue, antibody and antigen - and, finally, selected major figures such as Sir John Hill, Joseph von Gerlach, Rudolf Heidenhain, Paul Mayer, Paul Unna, Paul Ehrlich, Walther Flemming, John Belling, Gustav Mann, Frank Mallory and Ralph Lillie. It is not clear why Rudolf Heidenhain was chosen rather than his son Martin, author of the iron-haematoxylin staining procedure and pioneer in the use of aniline dyes, but the other figures are reasonable choices.

The early history of biological staining centres on the use of carmine from the cochineal insect and haematoxylin from extract of logwood. Next came the aniline dyes, following upon Perkin's production of "mauve" in 1856 - safranin, methyl violet, aniline blue, eosin, methyl green, methylene blue, acid fuchsin and so on. The golden era of cytology in the 1880 s and $1890 \mathrm{~s}$, in which the details of the chromosomes, and the nature of cell division and fertilization were revealed, rested upon the growing range of stains and techniques described in the book.

The history of the relationship between histochemistry and cytology is a fascinating one which goes back to the very early days. In his chapter on protein and nucleic acid histochemistry, Professor Kasten takes us back to François-Vincent Raspail's use of the starch-iodine reaction in 1825. He stresses the importance of Miescher's and Zacharius's study of the relation between nuclear staining and the chemistry of the nucleus. But it was
Feulgen's "nucleal reaction" which Kasten sees as the decisive influence in establishing the localization of proteins and nucleic acids in the cell, paralleling the distinctive staining reactions of nucleus and cytoplasm, and overturning the old belief in the restriction of DNA to animal tissues and RNA to those of plants.

There are obvious difficulties in writing about a collection of techniques and leading technicians for anyone but specialists. No doubt this text will be much appreciated by them. The general reader, however, will surely require a very different sort of book, one organized not around specific stains and famous figures but concentrating on general issues, such as the much-debated question of the existence of organized structures in the cell, their persistence and their replication. Intimately connected with this issue were fundamental questions over the nature of fixing and staining themselves. Did the process of fixing create structures which then adsorbed the stains to produce a spurious architecture within the cell? Was staining simply physical adsorption as Albert Fischer maintained? Were the cytoplasmic organelles discovered in the nineteenth century mere artefacts as W. B. Hardy held? This debate is mentioned on p. 199 but not developed. From the book, one would not have guessed that the tenets of cytology were seriously undermined by these fundamental criticisms, and that the emerging tradition of experimental cytology, its practitioners having become sceptical of the claims of classical cytology, concentrated upon the biophysical properties of protoplasm and the presence of surface phenomena in the cytoplasm.

Needham and Peters in the 1930s envisaged a "cytoskeleton" in the cytoplasm which was a colloidal formation and not an organelle in the sense of classical cytology. This rejection of the tradition of classical cytology was not reversed until the techniques of freeze-drying, electron microscopy and ultracentrifugation had been introduced in the 1930s and successfully developed in the 1940 s. Kasten points out how important was Feulgen's "nucleal reaction" in this change of opinion. It should also be stressed that histochemists were in the van of the movement beginning in 1950 to establish nucleic acids rather than proteins as the hereditary material. This decision arose from the results of the quantitative study by histochemists of the content of DNA and protein in the chromosome cycle of dividing cells and from the discovery of the halving of DNA content during reduction division. That the contribution of the histochemists is often ignored suggests that this tradition has yet to receive a just evaluation from historians. The present book offers an introduction and valuable bibliography for any such attempt.

Robert Olby is Reader in the History of Science at the University of Leeds. 